\title{
IN-SILICO STUDY OF BIOACTIVE COMPOUNDS OF NATURAL MATERIALS AS A JAK- SIGNAL TRANSDUCER AND ACTIVATOR OF TRANSCRIPTION INHIBITOR FOR ANTI-ALOPECIA
}

\author{
RESMI MUSTARICHIE*, SANDRA MEGANTARA, NYI MEKAR SAPTARINI
}

Department of Pharmaceutical Analysis and Medicinal Chemistry, Faculty of Pharmacy, Universitas Padjadjaran, Indonesia. Email: resmi.mustarichie@unpad.ac.id

Received: 05 July 2017, Revised and Accepted: 08 August 2017

\section{ABSTRACT}

Objective: This study aims to examine the compounds contained in herbs for the treatment of anti-alopecia by in-silico computation.

Methods: JAK (Janus Kinase) regulates the activation of key hair follicle populations such as the hair germ and improves the inductivity of cultured human dermal papilla cells by controlling a molecular signature enriched in intact, fully inductive dermal papillae. JAK2 which was a member of Janus family was used in this study as a receptor (PDB code: 4C61) and 15 compounds normally found in five herbals traditionally used as hair growth as ligands. Molecular modeling of bioactive compounds was performed using MarvinSketch and Prediction of physicochemical properties by ligand scout software. Molecular docking was performed using ligand scout, AutoDock Vina, and PyMOL. Binding affinity (Ei), inhibition constant (Ki), hydrogen bond interaction, and hydrophobic interaction were evaluated to find which of herbs potentially for anti-alopecia.

Results: Among 15 compounds studied three of them, 6-hydroxy genistein, coreximine, and scoulerine interacted well with JAK2's active pocket so it can inhibit JAK- signal transducer and activator of transcription. 6-hydroxy genistein interacted with Asp994, Gly993 Met929, Val863, Leu983, Ala880, and Leu855 whereas coreximine and scoulerine interacted with Leu932, Pro933, Tyr931 and Pro933, Tyr931, Ala880, Val863, Leu983, Leu855, respectively.

Conclusion: These results predicted that three compounds, namely, 6-hydroxy genistein, coreximine, and scoulerine which come from Dadap leaves (Erythrina variegata var. orientalis (L.) Merr.) were strongly had the link with JAK2 indicating that this plant extract may be used as hair growth agent/ anti-alopecia. As compounds studied was based on the literature survey, our results suggest compounds from six herbals studied should firstly be tested in-vivo for its anti-alopecia activity, fractionated, elucidated, to check as to whether their compounds responsible for anti-alopecia using the method developed in this paper.

Keywords: Anti-alopecia, Molecular docking, Herbal medicine, In-silico, JAK2

(C) 2017 The Authors. Published by Innovare Academic Sciences Pvt Ltd. This is an open access article under the CC BY license (http://creativecommons. org/licenses/by/4. 0/) DOI: http://dx.doi.org/10.22159/ajpcr.2017.v10i11.21118

\section{INTRODUCTION}

Hair as one of the organs of the human body has an important role. Hair has the function of them to protect the skin from the surrounding environment and has the aesthetic function to support one's appearance. For women, the hair is considered a crown whereas for men the hair can play a role in improving self-confidence baldness caused by hair loss can lead to a decrease in confidence to the frustration of a person [1-4]. Hair is often used as a symbol to show relationships to groups, tribes, or cultures and acts as a form of identity [5].

Some plants in Indonesia have traditionally been widely known and used to help stimulate hair growth. Some of them have been scientifically reported, such as aloe vera [6], hibiscus flowers [7], red onion [8], garlic [9], tea [10], ginseng [11], and celery [12]. Here are some plants that are also thought to be nutritious hair growth. Iqbal and Sulistyorini [13] reported that leaves, flowers, and roots of Hibiscus rosa sinensis contain flavonoids, saponins, and polyphenols, flowers contain polyphenols, their roots also contain tannins, saponins, scopoletin, cleomiscosin A, and cleomiscosin C. The katuk (Sauropus androgynus) leaf contains 1.14-tetradecanediol, 1-octadecin, 1-hexadecin, ductid acid, ethyl ester, phytol, pyrene, hexadecahydro, $2(1 \mathrm{H})$ naphthalenone, 3,5,6,7,88a-hexahidro- 4,8a -dymethyl-6- (1-methylethenyl) -, azulene, 1,2,3,5,6,7,8,8a-octahydro-1,4-dimethyl- (1-methenylene) -, [1- Metiletenil) -, squalene [14]. Chemical content in the Sunan herbs (Reutealis Trisperma (Blanco) Airy Shaw) is a $50 \% \alpha$-oleo stearic acid that has the properties of toxins. In addition, there are other dominant contents in the oil that is triglyceride compounds such as oleic acid, palmitic acid, and linoleic acid [15]. Research conducted by Kusmardiyani et al. [16] showed A flavonoid was isolated from aqueous fraction of green grass jelly (Cyclea barbata Miers) leaf extract. On the basis of paper as well as thin layer chromatographic pattern, acid hydrolysis, and ultraviolet-visible spectrophotometric analysis, the isolate was confirmed as a 3-0-glycosidic flavonol with a hydroxyl group at $\mathrm{C}-4$ ' and an 0 -di $\mathrm{OH}$ of A ring at a position of either 6,7 or 7,8. The chemical content contained in the hantap (Sterculia coccinea) leaves is alkaloids, flavonoids, and tannins [17]. Dadap Leaf (Erythrina variegata) is known to contain alkaloid and tannin group compounds [18]. It is reported as well that the dadap leaves contain isoflavones such as epilupeol, 6-hydroxy genistein, and 3 $\beta$, 28-dihydroxyolean-12-ene [19]. In other studies, also known compounds contained in leaves of dadap that are scoulerine, coreximine, l-reticuline, and erybidine [20].

The use of in-silico study in a prediction of chemical compounds activities have been reported by researchers. Begum et al. [21] reported their attempt to identify novel plant-based compounds which may be effective against pediatric epilepsy syndrome, to meet this demand for newer drugs with minimal side effects. In-silico analysis of proteins of Curcuma caesia was reported by Bharathi [22]. Harel et al. [23] in their in-silico study mentioned that the Janus kinase (JAK)-signal transducer and activator of transcription pathway results in rapid onset of anagen and subsequent hair growth. JAK inhibition regulates the activation of key hair follicle populations such as the hair germ and improves the inductivity of cultured human dermal papilla cells by controlling a molecular signature enriched in intact, fully inductive dermal papillae. 
They also mentioned treatment with the JAK inhibitors resulted in rapid reentry into the hair cycle, with kinetics similar to the $\mathrm{SHH}$ agonist. JAK2 is a member of Janus kinase and provides instructions for making a protein that promotes the growth and division (proliferation) of cells. In this study, the JAK2 was used as receptor and the chemical compounds used in herbal as the ligand [24]. This study will be based on the modification of our previously developed method [25-27]. This paper shows the prediction of their link and behavior to find the chemical compound which is responsible for hair growth.

\section{MATERIALS AND METHODS}

Methods were carried out by modification of Mustarichie et al. [25-27] methods.

\section{Tools}

Hardware used for the calculations, molecular modeling, and molecular docking involves a personal computer, MacBook Pro (13-inch, Mid 2012), with macOS Sierra Which Processor $2.5 \mathrm{GHz}$ Intel Core i5, completed with Graphics Intel HD Graphics $40001536 \mathrm{MB}$, and memory of $16 \mathrm{~GB} 1600 \mathrm{MHz}$ DDR3.

The software used was as follows:

1. MarvinSketch 17.11.0 (Academic License)

2. Ligand scout 4.1.4 (Universitas Padjadjaran License)

3. Autodock Vina 1.1

4. MacPyMOL: PyMOL 1.7.4.5 Edu.

\section{Materials}

15 chemical compounds from five herbals were used as ligands which were from a literature search. The crystal structure of JAK2 was obtained from Protein Data Bank (PDB code: 4C61) [24].

\section{Research methods}

1. Two-dimensional structure of 15 chemical compounds as ligands were drawn using MarvinSketch.

2. Three-dimensional molecular modeling and geometry optimization using MMFF94 on ligand scout software.

3. Physicochemical properties of ligands were predicted using ligand scout.

4. Molecular docking of 15 chemical compounds to JAK2 receptor obtained using ligand scout with AutoDock Vina and PyMOL for visualization.
5. Binding affinity, inhibition constant, and binding interaction studies of ligands to a receptor to obtain the best potential as the JAK2 inhibitor for anti-alopecia.

\section{RESULTS AND DISCUSSION}

The first step in the preparation of the ligand was making a twodimensional structure with MarvinSketch Software as shown in Table 1.

The three-dimensional structure then geometry optimized to obtain the most stable conformation.

Conformational changes and physicochemical properties prediction of the 15 ligands were shown by ligand scout's window in Fig. 1.

From data obtained by ligand scout, Principle Lipinski's rule of five [28] was used as a reference to determine the effectiveness of the theoretical and bioavailability of an oral drug that was used. Principle Lipinski's rule of five is the first compound mass not more than 500 daltons. Mass owned except by compound 4, 5, 7, 11, and 12 had met the criteria as oral medications which could produce an effect. Requirements Lipinski's Rule of five others were reviewing the physical properties of a compound was the value of the partition coefficient (clog P). Clog P values (log P calculation) shows the value of $\log \mathrm{P}$ (lipophilicity) resulting from the computational calculations. Clog $\mathrm{P}$ value is proportional to the value of $\log \mathrm{P}$. Clog $\mathrm{P}$ values is in the range of good value according to Lipinski's rule of five (A good range is -2 $<\log \mathrm{P}<5$ ) so that both compounds are predicted to easily penetrate the membrane. The partition coefficient is the ratio of fat solubility concentration values with the concentration in the water.

The partition coefficient of compounds met the criteria according to Lipinski's rule of five, which was under 5 and $<-2$. The negative sign on the coefficient of compounds No. 1 showed that the two compounds were hydrophilic. This means that these compounds would easily be dissolved in water or body fluids so that the process of distribution to achieve the longer the cell 74 membranes. Unlike the clog P compound No. 11 which had close to five. This suggested that this compound had the ability to penetrate the cell membrane was higher than other compounds because it was more lipophilic. As we were looking for topical medicines, this result would not affect to our aim.

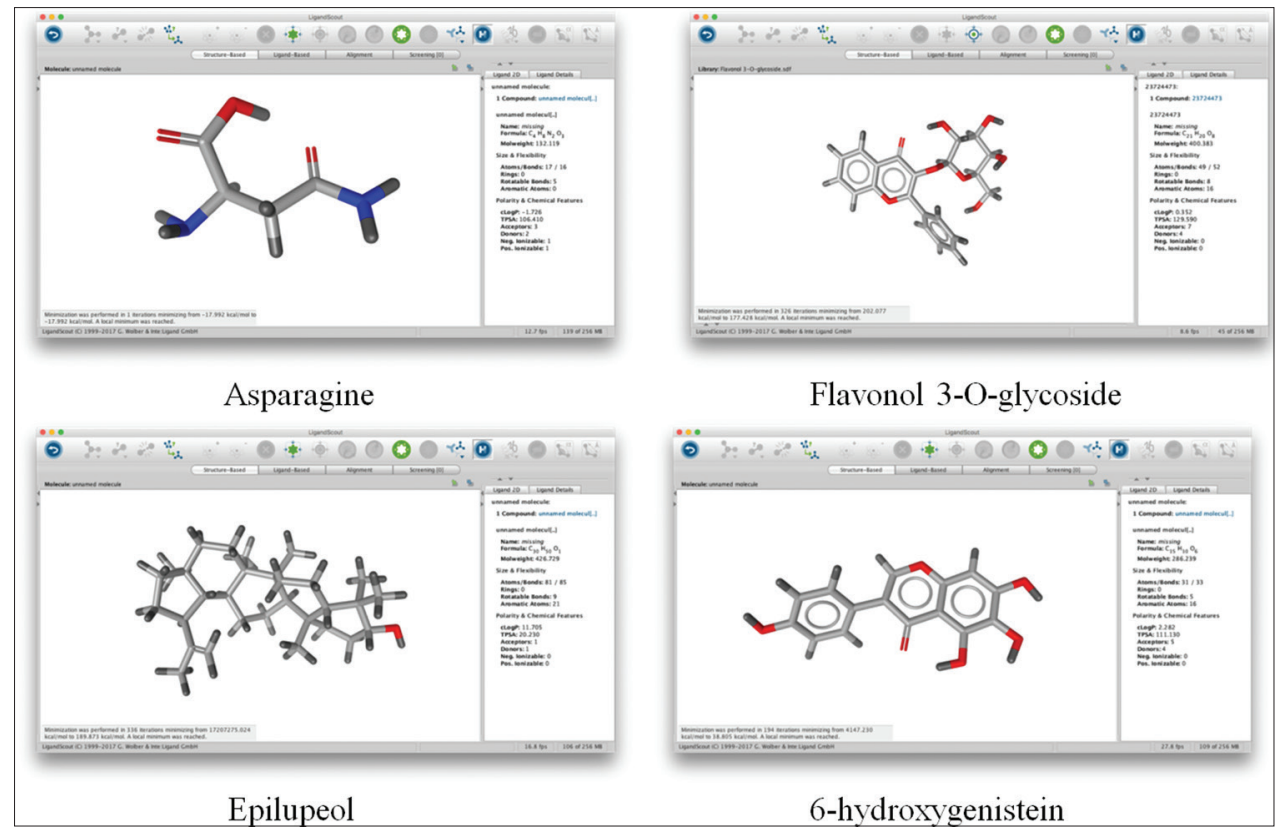

Fig. 1: 3D conformation and physicochemical properties prediction of four out of 15 ligands studied 
Table 1: Molecular modeling of secondary metabolite compounds, 2D structure, using MarvinSketch software

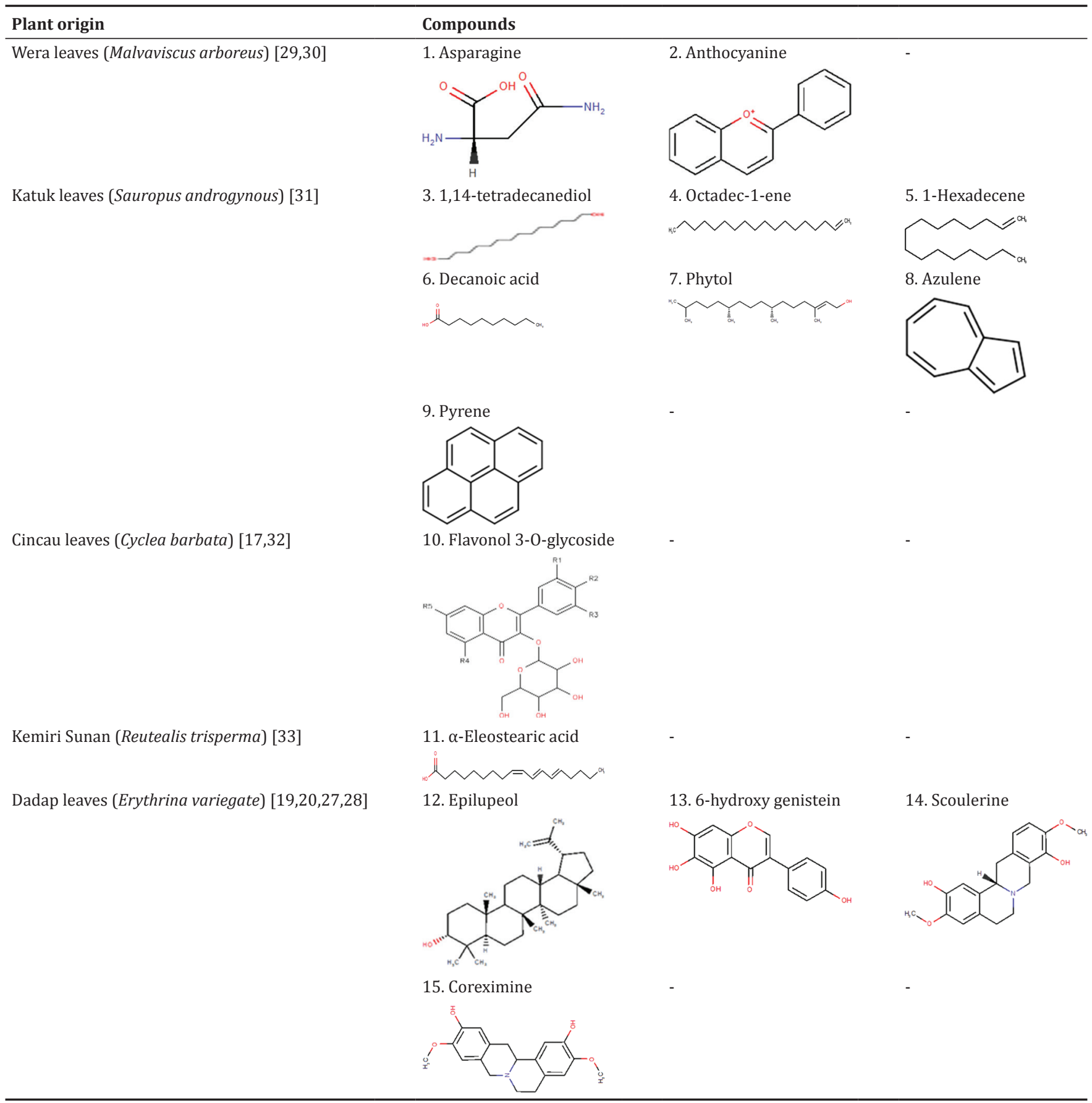

Herewith, we give four windows of how the docking was carried out.

\section{Asparagine}

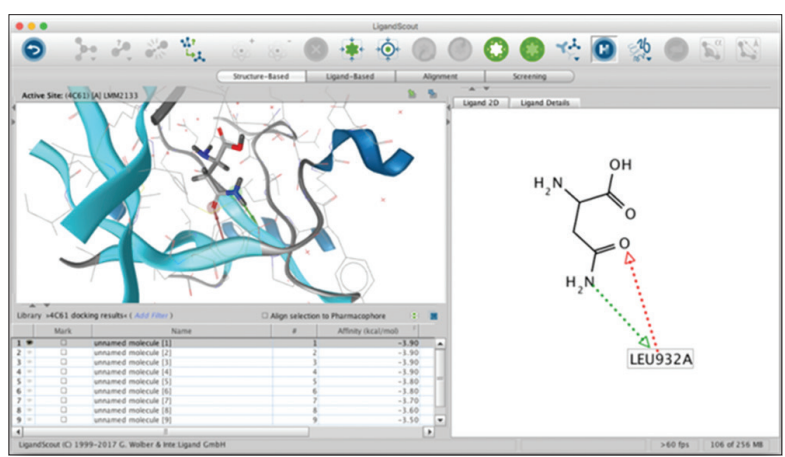

2. Anthocyanin

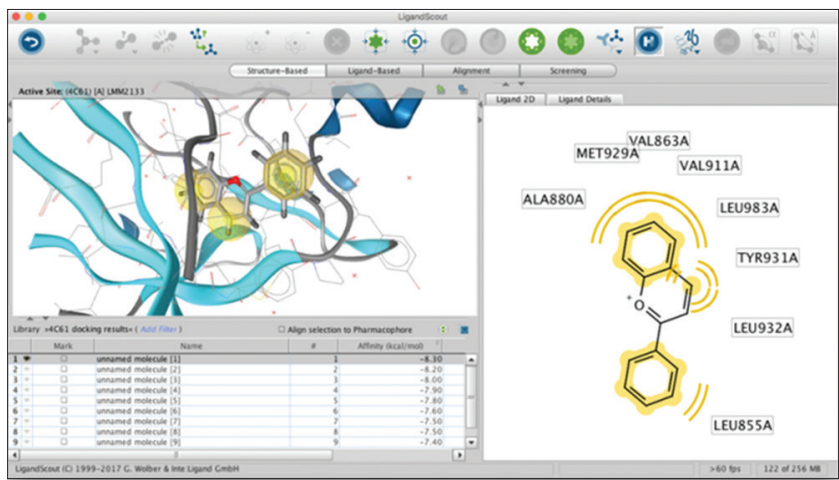




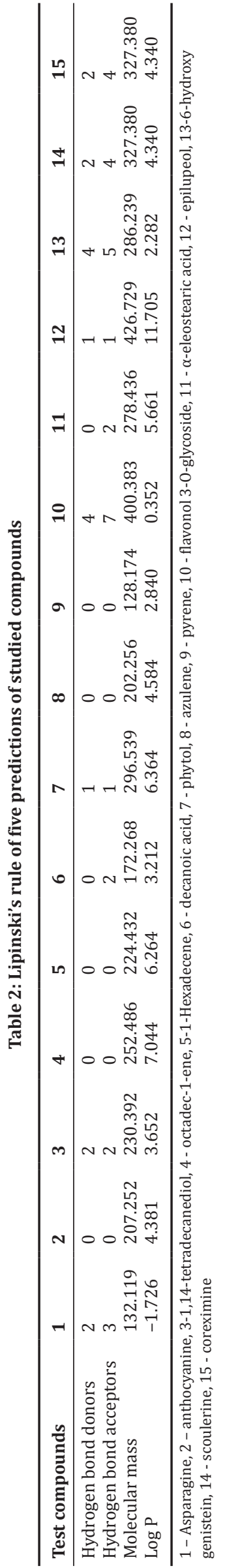

3. Flavonol 3-0-glycoside

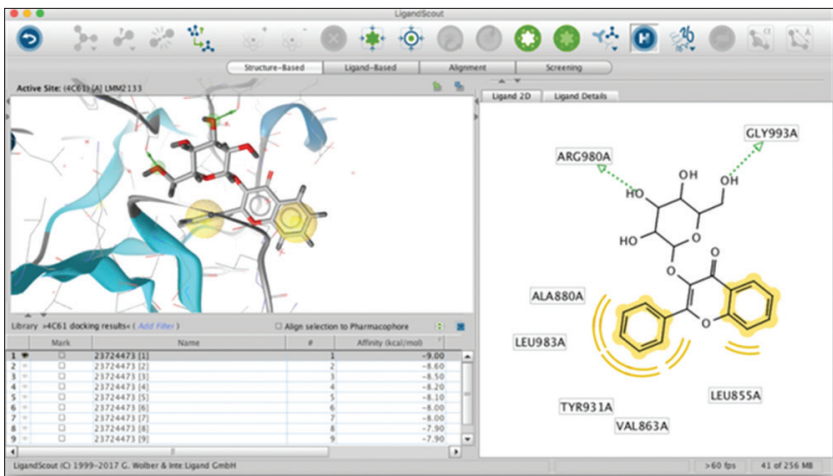

4. Scoulerine

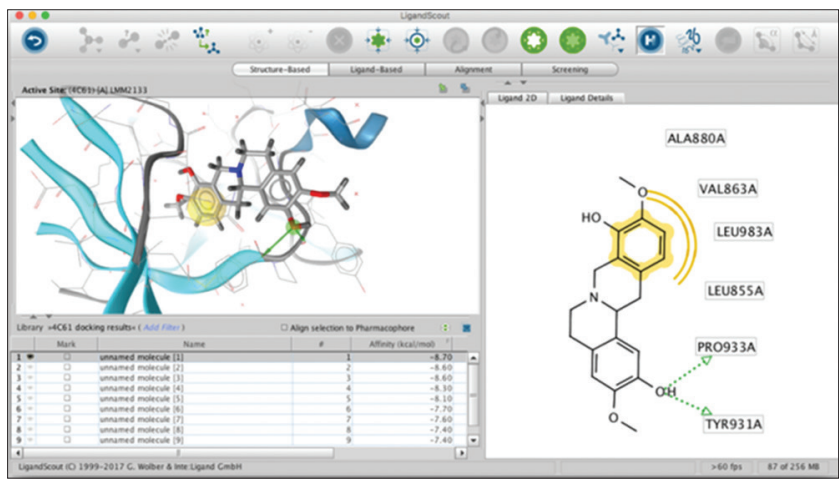

Results of molecular docking were then summarized in Tables 2 and 3 and Fig. 2.

Judging from the above data Table 3 and Fig. 3, compounds had the lowest bond energy was considered the most easily interact with the JAK2 receptor, less binding affinity assessed more easily interact with the receptor $[29,30]$. Ki value should be $<1 \mu \mathrm{M}$. Hence, six out of 15 compounds had the ability to bind to JAK2. From this research data, Table 4 shows its summary.

Among 15 tested compounds, only six of them predictive able to bind with JAK2. Pyrene has low Ki having the binding affinity (Ei) of $-9.50 \mathrm{kcal} / \mathrm{mol}$, did not have either hydrogen donor or acceptor so there was no hydrogen bonding to a Jak2 receptor, but it interacted hydrophobically through Leu855, Leu983, Val911, Met929, Ala880, Val863, and Tyr931. This

Table 3: Molecular docking results

\begin{tabular}{|c|c|c|}
\hline \multirow[t]{2}{*}{ Test compounds } & \multicolumn{2}{|l|}{ Docking score } \\
\hline & $\begin{array}{l}\text { Binding affinity (Ei) } \\
\text { Kcal/mol }\end{array}$ & $\begin{array}{l}\text { Inhibition } \\
\text { constant }(\mathrm{Ki}) \mu \mathrm{M}\end{array}$ \\
\hline Asparagine & -3.90 & 1388.11 \\
\hline Anthocyanin & -8.30 & $0.83^{*}$ \\
\hline 1,14-tetradecanediol & -5.10 & 183.30 \\
\hline Octadec-1-ene & -4.80 & 304.08 \\
\hline 1-Hexadecene & -4.80 & 304.08 \\
\hline Decanoic acid & -4.80 & 304.08 \\
\hline Phytol & -5.90 & 47.53 \\
\hline Pyrene & -9.50 & $0.11^{*}$ \\
\hline Azulene & -6.50 & 17.27 \\
\hline Flavonol 3-0-glycoside & -9.00 & $0.25^{*}$ \\
\hline 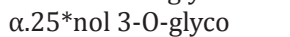 & -5.40 & 110.50 \\
\hline Epilupeol & -7.50 & 3.20 \\
\hline 6-hydroxygenistein & -9.20 & $0.18^{*}$ \\
\hline Scoulerine & -8.70 & $0.42 *$ \\
\hline Coreximine & -9.00 & $0.25^{*}$ \\
\hline
\end{tabular}

* Ki values $<1 \mu \mathrm{M}$ 
Table 4: Test compounds potentially as JAK2 inhibitors for anti-alopecia

\begin{tabular}{|c|c|c|c|c|}
\hline Compounds & Ki (oun) & Plant origin & $\begin{array}{l}\text { Interaction of } \\
\text { hydrogen bonding }\end{array}$ & Hydrophobic interaction \\
\hline Pyrene & 0.11 & Katuk leaves (Sauropus androgynous) & - & $\begin{array}{l}\text { Leu855, Leu983, Val911, Met929, } \\
\text { Ala880, Val863, Tyr931 }\end{array}$ \\
\hline 6-hydroxygenistein & 0.18 & Dadap leaves (Erythrina variegate) & Asp994, Gly993 & Met929, Val863, Leu983, Ala880, Leu855 \\
\hline Flavonol 3-0-glycoside & 0.25 & Cincau leaves (Cyclea barbata) & Arg980, Gly993 & Ala880, Leu983, Tyr931, Val863, Leu855 \\
\hline Coreximine & 0.25 & Dadap leaves (Erythrina variegate) & Leu932, Pro933, Tyr931 & - \\
\hline Scoulerine & 0.42 & Dadap leaves (Erythrina variegate) & Pro933, Tyr931 & Ala880, Val863, Leu983, Leu855 \\
\hline Anthocyanin & 0.83 & Wera leaves (Malvaviscus arboreus) & & $\begin{array}{l}\text { Ala880, Met929, Val863, Val911, Leu983, } \\
\text { Tyr931, Leu932, Leu855 }\end{array}$ \\
\hline
\end{tabular}

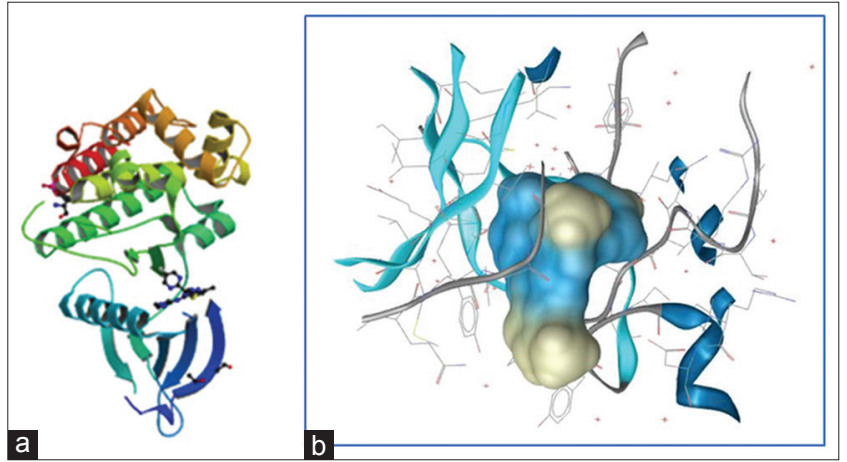

Fig. 2: (a and b) JAK2 crystal structure and binding pocket (4C61)

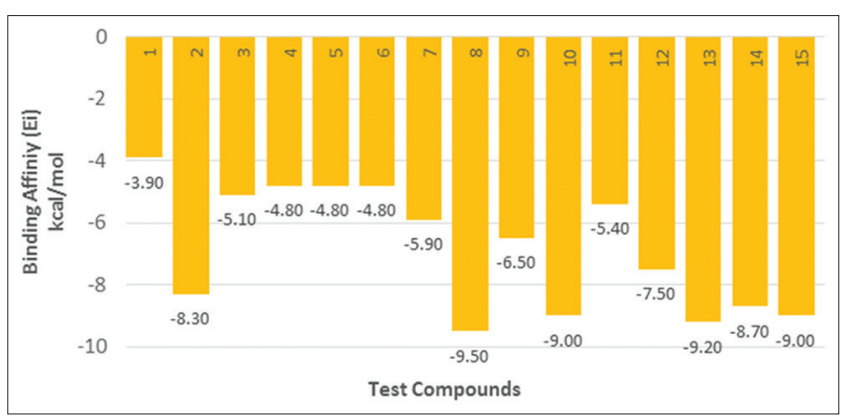

Fig. 3: Molecular docking score

trait is similar to anthocyanin. Coreximine, however, only had hydrogen bonding activity through Leu932, Pro933, and Tyr931. A hydrogen bond is a bond between the $\mathrm{H}$ atom that has a partial positive charge with other atoms that are electronegative and has a lone pair with octets complete, such as $\mathrm{O}, \mathrm{N}$, and $\mathrm{F}$ [31]. It should be noted that ring aromatic donating properties of non-polar to a compound.

Interaction energy or free energy is the energy required for a ligand can enter into binding pockets and interact with the receptor. The negative sign indicates that the compounds can interact spontaneously with the receptor. According to Siswandono and Soekardjo [32], an amino acid which is about 4-6 $\AA$ will form Van der Waals interactions. Although the Van der Waals bonds are weak, the sum of Van der Waals bonding is a substantial binding factor, especially for compounds with high molecular weight. Van der Waals interactions also give effect to the lipid solubility of the ligand. The more the Van der Waals interaction that happens it will be easier ligand is soluble in lipid ligands that can penetrate the cell membrane to be able to bind to the receptor. Low $\mathrm{Ki}$ value indicates that the ligand has a higher strength than the Ki values were higher (weaker bond strength). A good values range of Ki is 10-6-10-12 M. When ligands bound to the receptor too powerful, the ligand will be difficult excreted from the body and the ability to cause an activity is inhibited, but when the ligand binds weakly to the receptors, the ligands will be easily removed before generating an activity. The absence of hydrogen bonds in the interaction suggests that the ability to bind to receptor weaker compared to compounds which have hydrogen binding affinity.

A number of hydrogen bonds formed in the ligand-receptor interaction depend on the presence of atomic $\mathrm{H}, \mathrm{O}, \mathrm{N}$, or S ligands which are located around the $\mathrm{H}$ atom acts as a hydrogen bond donor, while $\mathrm{O}$ atoms, $\mathrm{N}$, and $\mathrm{S}$ acts as a hydrogen bond acceptor. According to Bohm and Schneider [31], the range of hydrogen bond distances are good docking simulation results are 1.72-2.85 $\AA$. The four compounds had bond distances in the range, in other words, that the four compounds had a hydrogen bond distance corresponding requirements so that they all could interact with the tyrosinase enzyme. Curcumin formed Van der Waals bond with the amino acids in $\alpha$-MSH with DPN4 (4,645 $)$ and Cys7 (4,571 $\AA$ ). Van der Waals interaction is the force of attraction between molecules and atoms are not charged and are located adjacent to the bond strength of $0.5-1 \mathrm{kcal} / \mathrm{mol}$ [28]. According to Siswandono and Soekardjo [32], amino acids that are about 4-6A will form Van der Waals interactions. Although the Van der Waals bonds are weak, the sum of Van der Waals bonding is a substantial binding factor, especially for compounds with high molecular weight. Van der Waals interactions also give effect to the lipid solubility of the ligand. The more the Van der Waals interaction that happens it will be easier ligand is soluble in lipid ligands that can penetrate the cell membrane to be able to bind to the receptor.

\section{CONCLUSIONS}

These results predicted that three compounds, namely, 6-hydroxy genistein, coreximine, scoulerine which come from Dadap leaves (E. variegata var. orientalis (L.) Merr.) were strongly had a good interaction with JAK2 indicating that this plant extract may be used as hair growth agent/anti-alopecia. As compounds studied was based on the literature survey, our results suggest compounds from six herbals studied should be first tested in-vivo for its anti-alopecia activity, fractionated, elucidated, and to checked as to whether their compounds responsible for anti-alopecia using the method developed in this paper.

\section{ACKNOWLEDGMENT}

We thank ALG (Academic Leadership Grant) Universitas Padjadjaran 2017 for funding this research.

\section{REFERENCES}

1. Kirtishanti K, Agustina A, Aryani A, Dewi NL, Jessy M. The Abilities of Hair Tonic Extracts of Apple Skin Extract (Malus sylvestris L.) Var. Rome Beauty in Growing Mouse Hair (Kemampuan Sediaan Hair Tonic Ekstrak Kulit Apel (Malus sylvestris L.) Var. Rome Beauty Dalam Menumbuhkan Rambut Tikus), Prosiding Simposium Penelitian Bahan Obat Alami XV \& Kongres Obat Tradisional Indonesia IV. Surakarta; 2011. p. 217-29.

2. Dalimartha S, Soedibyo M. Hair Care with Medicinal Plants and Diet Supplements (Perawatan Rambut Dengan Tumbuhan Obat dan Diet Suplemen). Bogor: PT. Penebar Swadaya; 1998. p. 4-18.

3. Stough D, Stenn K, Haber R, Parsley WM, Vogel JE, Whiting DA, et al. Psychological effect, pathophysiology, and management of androgenetic alopecia in men. Mayo Clin Proc 2005;80(10):1316-22. 
4. Jain R, Monthakantirat O, Tengamnuay P, De-Eknamkul W. Identification of a new plant extract for androgenic alopecia treatment using a non-radioactive human hair dermal papilla cell-based assay. BMC Complement Altern Med 2016;16:18.

5. Birngruber CG, Verhoff MA. The color of human hair. Human Health Handbooks. Vol. 1. Washington, DC: Washington Academic Publishers; 2012. p. 30-49.

6. Kaushik K, Gupta D, Yadav R. Alopecia: Herbal remedies. Int J Pharm Sci Res 2011;2(7):1631-4.

7. Thorat RM, Jadhav VM, Kadam VJ. Development and evaluation of polyherbal formulations for hair growth-promoting activity. Int $\mathrm{J}$ PharmTech Res 2009;1(4):1251-4.

8. Sharquie KE, Al-Obaidi HK. Onion juice (Allium cepa L.), A new topical treatment for alopecia areata. J Dermatol 2002;29(6):343-6.

9. Hajheydari Z, Jamshidi M, Akbari J, Mohammadpour R. Combination of topical garlic gel and betamethasone valerate cream in the treatment of localized alopecia areata: A double-blind randomized controlled study. Indian J Dermatol Venereol Leprol 2007;73(1):29-32.

10. Esfandiari A, Kelly AP. The effects of tea polyphenolic compounds on hair loss among rodents. J Natl Med Assoc 2005;97(8):1165-9.

11. Prager N, Bickett K, French N, Marcovici G. A randomized, doubleblind, placebo-controlled trial to determine the effectiveness of botanically derived inhibitors of 5-alpha-reductase in the treatment of androgenetic alopecia. J Altern Complement Med 2002;8(2):143-52.

12. Kuncari ES, Iskandarsyah I, Praptiwi P. Test irritation and activity of white rat hair growth: Apigenin gel preparation effect and herbal celery (Apium graveolens L.) (Uji iritasi dan aktivitas pertumbuhan rambut tikus putih: Effek sediaan gel apigenin dan perasan herba seledri (Apium graveolens L.)). Med Litbangkes 2015;25(1):15-22.

13. Iqbal M, Sulistyorini E. Kembang Sepatu (Hibiscus rosa-sinensis L). Available from: http://www.ccrc.farmasi.ugm.ac.id/?page id=217. [Last downloaded on 2017 Mar 14].

14. Senthamarai SV, Anusha B. Phytochemical analysis and GC-MS profiling in the leaves of Sauropus androgynus (L) Merr. Int J Drug Dev Res 2012;4(1):162-7.

15. Martin C, Moure A, Martin G, Carrillo E. Fractional characterisation of jatropha, neem, moringa, trisperma, castor and candlenut seeds as potential feedstocks for biodiesel production in Cuba. Biomass Bioenergy 2010;34:533-8.

16. Kusmardiyani S, Insanu M, Al-Asyhar M. Effect a glycosidic flavonol from green grass jelly extract (Cyclea barbata L. Miers) leaves. Proc Chem 2014;13:194-7.

17. Effendi N. Standardize simplicia of Hantap leaves (Sterculia coccinea Jack.) oigin of donggala district of central sulawesi province as phytopharmaca raw materials. J Sainsmat 2012;1(1):23-32.

18. Rahman MZ, Sultana SZ, Faruquee CF, Ferdous F, Rahman MS,
Islam MS, et al. Phytochemical and biological investigation of Erythrina variegata. Saudi Pharm J 2007;15(2):140-5.

19. Warara SG, De Queljoe E, Simbala H. Identification of phytochemical compounds and toxicity test of ethanolic extract of Lola kahori leaf (Erythrina variegata L.) from tidore islands using scientific method, PHARMACON J Ilmiah Farmasi 2016;5(3):103-9.

20. Ravishankar B, Shukla VJ. Indian systems of medicine: A brief profile. Afr J Tradit Complement Altern Med 2007;4(3):319-37.

21. Begum BS, Subashini S, Hemalatha P, Archana P, Bharathi N, Nagarajan. P. In silico screening of phytochemical compounds targeting Childhood Absence Epilepsy (CAE). Int J Pharm Pharm Sci 2014;6(5):430-3

22. Bharathi SV. In silico analysis of proteins of Curcuma caesia Roxb. Int J Pharm Pharm Sci 2014;6(2):216-20.

23. Harel S, Higgins CA, Cerise JE, Dai Z, Chen JC, Clynes R, et al. Pharmacologic inhibition of JAK-STAT signaling promotes hair growth. Sci Adv 2015;(1):e1500973.

24. Su Q, Ioannidis S, Chuaqui C, Almeida L, Alimzhanov M, Bebernitz G, et al. Discovery of 1-methyl-1H-imidazole derivatives as potent Jak2 inhibitors. J Med Chem 2014;57(1):144-58.

25. Mustarichie R, Warya S, Moektiwardoyo M, Megantara S, Saputri FA. Docking, absorption, distribution, metabolism and toxicity prediction of anticancer compounds found in plants. World J Pharm Pharm Sci 2014;3(10):72-90

26. Mustarichie R, Levita J, Arpina J. In silico study of curcumol, curcumenol, isocurcumenol, and $\beta$-sitosterol as potential inhibitors of estrogen receptor alpha of breast cancer. Med J Indones 2014;23(1):15-24

27. Mustarichie R, Levita J, Febriani D. In-silico study of curcumin, demethoxycurcumin, xanthorriizol as skin whitening agents. World $\mathrm{J}$ Pharm Sci 2013;1(3):72-80.

28. Lipinski CA, Lombardo F, Dominy BW, Feeney PJ. Experimental and computational approaches to estimate solubility and permeability in drug discovery and development settings. Adv Drug Del Rev $1997 ; 23: 3-25$.

29. Kitbunnadaj R. Histamine receptors and their ligands. Naresuan Univ J 2005;13(3):41-53

30. Kiss R, Jozan M, Ferenczy G, Tapolcsanyi P. Structural Analysis of Histamine Receptors and Its Application in Drug Design, Thesis. Budapest: Semmelweis University; 2008.

31. Purwanto P, Susilowati R. Chemical bonding and biological activity (Ikatan kimia dan aktivitas biologis). In: Siswandono S, Soekardjo B, editors. Principles of Drug Design (Prinsip-Prinsip Rancangan Obat). Surabaya: Airlangga University Press; 1998. p. 65-80.

32. Siswandono S, Soekardjo B. Medicinal Chemistry (Kimia Medisinal). Surabaya: Universitas Airlangga; 1995. p. 194-5. 